\title{
What was the law of Leptines' really about? Reflections on Athenian public economy and legislation in the fourth century BCE
}

\author{
Mirko Canevaro $^{1}$ (D)
}

Published online: 23 March 2018

(C) The Author(s) 2018

\begin{abstract}
The article investigates a case study of fiscal policy formation in fourth century BCE Athens: that of the law of Leptines. The law was enacted but later challenged through a procedure of constitutional judicial review (graphe nomon me epitedeion theinai). Through a detailed analysis of the arguments at the trial, the article reconstructs the financial issues that the law was meant to solve, regarding the liturgical system and its wider implications. Recent scholarship has highlighted the complexity and sophistication of Athenian public finances and economic policy. The article finds a window into the debates from which the relevant institutions originated.
\end{abstract}

Keywords Public finances $\cdot$ Athens $\cdot$ Trade $\cdot$ Taxation $\cdot$ Ancient economy

\section{JEL Classification $\mathrm{F} 13 \cdot \mathrm{H} 2 \cdot \mathrm{H} 3 \cdot \mathrm{K} 4 \cdot \mathrm{N} 43$}

\section{Introduction: war, financial problems and trade in mid-fourth-century Athens}

Scholarship on the ancient Greek city-states has abandoned in recent years primitivist assumptions to acknowledge the extraordinary level of economic and fiscal

All references to ancient sources are according to the abbreviations of the Oxford Classical Dictionary: http://classics.oxfordre.com/staticfiles/images/ORECLA/OCD.ABBREVIATIONS.pdf. All references to Classical journals follow the abbreviations of L'Année philologique: http://www. annee-philologique.com/files/sigles_fr.pdf.

Mirko Canevaro

Mirko.Canevaro@ed.ac.uk

1 The University of Edinburgh, Edinburgh, Scotland, UK 
sophistication achieved by states such as Athens. Just a few years ago, the consensus was that the Greek city-states were characterised by primitive economies managed by a political class of dilettantes. Our picture is now radically changed, with historians such as Bresson (2000, 2015), Harris, Lewis (e.g. Harris-Lewis-Woolmer 2015, particularly the introduction by Harris and Lewis) and Ober (2015b) showing the high level of sophistication of economic activity and of the institutional framework that underpinned it. Equally significantly, Migeotte, in the monumental Les finances des cités grecques: aux périodes classique et hellénistique of 2014, has provided a comprehensive synthesis of the organisation of the public finances of the Greek citystates. ${ }^{1}$ To quote one reviewer, '[t]he main conclusion [of Migeotte's work] is that their public finances were well-resourced in a diversity of finely tuned, complementary ways, competently run in terms of budget planning and book-keeping, with a savvy eye to the possibilities of public ownership of resources (hence taxes but also rents and fees), and simply of the fungibility of cash. The latter is a field in which Athens, both at the level of the central state and of the demes (with limited scope for taxation, multiple items expenditure, and a combination of landed resources and cash), played a pioneering role'. ${ }^{2}$ These results can be vividly illustrated by one fact observed by van Wees (2013: 1): Athens in the fourth century BCE spent more silver than France did during the Napoleonic Wars.

This new picture creates however new questions. Many of the studies above focus on institutions - on particular or widespread legal, political and fiscal arrangements that fostered growth. But once we recognise the sophistication of the public finances of the Greek city states, we are bound to wonder how wide-spread (and concentrated) economic and financial expertise was formed and performed in democratic political contexts where delegation was rare and imperfect, and major economic policy was decided by huge numbers of citizens attending the Assembly and the Council. ${ }^{3}$ One way to make inroads into this problem is to investigate, at the macro-level, the epistemic quality of Athenian (and Greek) democracy: how well did Athenian democracy succeed in aggregating scattered knowledge into sound policy decisions? This is the route taken in some very influential work by Ober $(2008,2013,2015 b)$.

My approach here focuses on the micro-level: on the formation of particular fiscal policy decisions, on the problems that these decisions tackled, on the naturethe effectiveness and the pitfalls — of the proposals made and on the debates that developed around them. The evidence is rarely fine-grained enough to allow us to follow these debates as they unfolded. But a prime case study is without a doubt mid-fourth century Athens. The inscriptional evidence, combined with plentiful literary evidence and with many speeches written by the Attic orators (and Demosthenes in particular) in the Assembly and in the lawcourts, allow us to reconstruct these debates, to dissect the proposals voiced and to follow the arguments in favour

\footnotetext{
${ }^{1}$ See also Pritchard (2015) and Ober (2015a).

2 J. Ma, Review of Migeotte (2014), BMCR 2015.08.27: http://bmcr.brynmawr.edu/2015/2015-08-27. html.

${ }^{3}$ Studies on the formation of financial expertise in ancient Greece are still rare, see e.g. Kallet-Marx (1994) and Davies (2004).
} 
and against some of these proposals. In this article, I shall focus on particular fiscal and economic policy proposals advanced in those central years and discussed in the Assembly and, more extensively, in the lawcourts, where they were examined in cases of constitutional judicial review.

To set the scene, I want to focus briefly on a key text about the Athenian public economy and its reliance on revenues from trade: Xenophon's Poroi. This text, whose title is usually translated as Ways and Means, has a subtitle in our manuscripts: peri prosodon, 'on state revenues'. The historical context in which Xenophon's treatise was written is that of 355/4, in the aftermath of the Social War. ${ }^{4}$ This war, started in 357/6 by powerful allies (or better, subjects) of Athens-Byzantium, Chios and Rhodes_-ended with Athens' defeat and the disintegration of its imperial ambitions. Athens was left for the second time in fifty-years without a real empire (apart from minor allies) and prostrated by war. ${ }^{5}$ In a speech written after the defeat, Isocrates (8.61-81) argued that Athens should finally abandon imperial ambitions. The city was economically exhausted: its revenues were down to 130 talents a year (Dem. 10.37). To get a sense of the gravity of the situation, it suffices to recall that a partially recovered Athens would manage in 346 to return to 400 talents a year in revenues (Dem. 10.37-8), and a few years after the defeat at Chaeronea against Philip II of Macedon (338 BCE), thanks to the wise administration of the politician Lycurgus, these would more than double again, going up to 1200 ([Plut.] Vit. $X$ Or. 842f). ${ }^{6}$ That Athens could recover from defeat and the loss of its most important allies and reach once again such heights of economic bonanza is a testament to the abilities of the administrators that controlled its public finances in those years, to the wisdom of the demos, and to the effectiveness of the democratic institutions. Xenophon's Poroi is one of a number of texts from the second half of the 350s that allow us to follow closely the debate on public finances that led to such a recovery. Many of Xenophon's proposals are found in the programmes of politicians such as Eubulus and Lycurgus. This is not to say that Xenophon was behind their political action. But he was certainly attuned to the solutions that were aired and discussed. ${ }^{7}$

Xenophon explains how Athens could increase the number of merchants and visitors, which would in turn increase exports and imports, and therefore sales, rents and customs, making up for the revenues lost with the empire (3.6-7). This could

\footnotetext{
${ }^{4}$ On Xenophon's Poroi see in particular Gauthier (1976, 1984), as well as, e.g. Dillery (1993), Bloch (2004) and Lewis (2010). Many of these studies are marred by various shades of a primitivist understanding of Greek economy, which has now grown progressively (and rightly) unpopular. Exceptions are Cawkwell (1963: 63-65), Giglioni (1970: xi-xv, xxxiii, lxii, lxx, lxxxviii, cvii, cxxx-cxxxii), Whitehead (1977: 125, 128), Lowry (1987: 49), Burke (1992: 208) and Sealey (1993: 113).

5 For a short summary of the war see Rhodes (2010: 75-76). For more detail and extensive bibliography see Sealey (1993: 102-136); Canevaro (2016a, b: 3-7, 323-325). The Second Athenian League was not dissolved, but Athens lost all the most important allies (see Paus. 1.25.3)

${ }^{6}$ Cfr. Theop. FGrH 115, F 166; Dem. 19.89; 8.45; 9.40; 10.38

7 On the development of fiscal expertise and institutions in Athens see in particular Davies (2004); cf. Pritchard (2015: 1-27) on Athenian debates on public finances, and passim on Athens' budget, and Ober (2015b) on Athenian finances. Cawkwell (1963) argues for a direct link between Eubulus' policies and Xenophon's proposals, noting that, according to Diog. Laert. 2.59, Eubulus sponsored Xenophon's recall from exile.
} 
be achieved with no need for direct investment, but rather through good legislation. Xenophon (3.1-5) stresses particularly the availability of silver coinage, thanks to the Laurion mines-he proposes to intensify their exploitation. The complex Athenian legislation on the mines, and the extant speeches in the orators concerned with disputes over mine concessions, show that during these years the Athenians did indeed implement measures to maximize their exploitation. ${ }^{8} \mathrm{He}$ also proposes that the Athenians should implement measures to ensure the expedite resolution of disputes arising from trade, so to make Athens the favourite trading partner, and these were actually introduced. ${ }^{9}$

Xenophon's final proposal is that front seats in the theatre should be offered to particularly meritorious traders, and that occasionally they may be entertained and dined at the Prytaneion. ${ }^{10}$ This way, traders would choose to come to Athens not only for profit, but also in the hope of receiving such honours. What Xenophon is talking about is public honours for benefactors of the city: these were reserved for euergetai (benefactors), victorious generals, magistrates that had distinguished themselves for their performance in office, and indeed for traders whose commercial activities were particularly vital for Athens. ${ }^{11}$ Such honours are attested earlier on, but they became in fact particularly prominent in the epigraphical record from the 350s. ${ }^{12}$ Granting such honours was one of the instruments used by the city to attract traders as well as foreign rulers that controlled essential goods for the city (e.g. grain) to give Athens preferential treatment. ${ }^{13}$

Xenophon's proposal was not as innovative as he seems to imply: these grants were already common. But their mention was probably connected to controversies at the end of the Social War. Issues of long term economic and trade policy were at the time at odds with the short-term needs for revenues to keep the machine of the state going. We find traces of such controversies in several speeches of Demosthenes, and in measures discussed and enacted in these years. ${ }^{14}$ Eubulus was probably the most incisive in tackling these problems, succeeding in increasing Athenian revenues to 400 talents per year. His success (Plut. Mor. 812ff.) was due to long-term policies,

\footnotetext{
${ }^{8}$ For an accessible discussion of these trials, and of the relevant legislation, see MacDowell (2006, 2009: 266-269). For mining operations in Athens, and their effectiveness, see now van Liefferinge (2018). For the leasing of mines see Hopper (1953, 1968), Aperghis (1997), Shipton (2000), and Rhodes and Osborne (2003).

9 The main book-length studies of these procedures are Cohen (1973) and Vélissaropoulos (1980). See now Harris (2015).

${ }^{10}$ See Canevaro (2016a, b: 220-221, 330-331).

11 On honours in Athens see Canevaro (2016a, b: 77-97).

12 Engen (2010: 276-325) identifies nine honorary decrees awarded for trade reasons before the 350s BCE, and 24 between 350 and 320 (see also Mitchell 1997: 142; Hagamajer Allen 2003: 237-238; Moreno 2007: 189; Lambert 2011: 178-179; 2012: 377-386; Liddel 2016: 311; Bissa 2009: 190-191; Canevaro 2016a, b: 77-98).

13 See Canevaro (2016a, b: 83-85) for honours available for foreign traders.

14 Schaefer (1885-1887: I, pp. 179-180, 361-363, 415-416) was the first to identify this economic policy. See Canevaro (2016a, b: 6-7) for examples.
} 
often in line with Xenophon's suggestions ${ }^{15}$ : efforts to re-establish the Piraeus' primacy with new legal procedures to resolve commercial disputes (dikai emporikai) quickly, ${ }^{16}$ investments in infrastructure for traders (Din. 1.96), investments in the Laurion mines (Dem. 19.293). ${ }^{17}$ Eubulus is also credited with restructuring Athenian finances by making the theorikon fund, which incentivised the citizens' participation to festivals by providing payments to those who attended, more central. ${ }^{18}$ He also sponsored investment in the water and road infrastructure (Dem. 3.29), and started a policy to strengthen the fleet, building new dockyards, wharves, and piers (IG II $^{2} 1613$ 1. 302; 505 11. 12-13; Din. 1.96; Aeschin. 3.25). He also participated in legal actions to acquire liquidity to tackle short-term financial problems, particularly against public debtors (Dem. 19.293; 21.218). Demosthenes was also part of these debates: he proposed in 354/3 BCE (Dion. Ad Ammaeum I, 1.4) to raise the number of citizens included in the trierarchic symmories (see Sect. 3), and in 349/8 BCE argued against the use of the military fund to pay for festival costs (Dem. 1.19-20, 3.10-13).

In this article, I focus on one legal case, that of Demosthenes' speech Against Leptines (20). This case had to do specifically with the balancing out of short-term issues of financial sustainability and longer-term targets of fostering foreign trade. The speech was written and pronounced by Demosthenes in 355/4 BCE for a graphe nomon me epitedeion theinai (public charge for enacting an inappropriate law), a procedure of constitutional judicial review to which all laws could be subjected for 'unconstitutionality'. Its aim was to repeal a law enacted by a famous politician, Leptines of Coile. ${ }^{19}$ It is particularly representative because it illuminates the political and legal constraints that Athenian institutions placed on reform of any kind, and particularly on financial reform. Many reform bills, apart from being discussed in the Council, the Assembly and often among the nomothetai, had to undergo constitutional judicial review, and were assessed for their coherence with the existing laws and the overall 'constitutional' spirit of the laws of the city (see Section 2).

It is clear that the law abolished previous grants of ateleia (tax exemption) and forbade such grants for the future. It went against Xenophon's advice: it took away from civic benefactors honours that had already been given, and prevented the Athenian state from using this instrument to foster trade. This is Demosthenes' main objection: it is wrong to take away honours already given to benefactors, and preventing the Athenians from honouring benefactors in the future will have disastrous effects on Athenian trade. What were Leptines' reasons for proposing such a law? And what was exactly the scope of the law? Did it apply to all forms of tax exemption? Regretfully we can only read Demosthenes' speech, one of the three accusation

\footnotetext{
15 Cawkwell (1963: 56), Oliver (2011: 122) and passim. Diog. Laert. 2.59 states that Eubulus sponsored Xenophon's return from exile.

16 Cawkwell (1963: 63-64), Sealey (1993: 116); cf. Engels (1988).

17 Cawkwell (1963: 64-65).

18 Cawkwell (1963: 55-61) and passim; against the existence of a law by Eubulus forbidding using the theorikon for military purposes, see Harris (1996: 57-76); cf. Oliver (2011: 122-123); for this fund see Faraguna (1992: 189-193). Roselli (2009) argues that this fund was created in this very period (cf. Rhodes 1981: 514).

19 For question about the trial that is not answered in this article see Canevaro (2016a, b), an extensive commentary of this speech. See also Kremmydas (2012).
} 
speeches. We do not have Leptines' defence speech, nor can we read those of Demosthenes' supporters. Even worse, we do not have the full text of Leptines' law, and, as it will become clear, Demosthenes is unreliable when representing its range of application and its consequences.

My aim is to reconstruct the actual provisions of Leptines' law, its range of application, and the problems it was meant to tackle. In the aftermath of the Social War, the Athenians enacted extensive legislation that tried to reinforce trade as a source of wealth for the city. At the same time, they dealt with an acute shortage of funds and contributors that endangered the most basic public services, particularly those funded through the liturgies - semi-voluntary financial performances in which an individual took charge of a particular public service (see Sect. 3). Xenophon (like Demosthenes) sheds light on one side of the debate: the importance of trade to increase revenues, and of honours to increase trade. Reconstructing the background of Leptines' law sheds light on the other side: the need for a steady flow of money (and liturgists) to secure in the short-term the orderly running of the state machine.

Sections 2 and 3 provide accounts of Athenian procedures for enacting new laws (and of constitutional judicial review), and of the Athenian liturgical system, as background for the discussion of Leptines' law. Section 4 discusses Leptines' law, the reasons for its enactment, the debates about Athenian finances from which it originated, and what this case study tells us about Athenian priorities in the midfourth century BCE.

\section{Lawmaking and constitutional judicial review}

The case against the law of Leptines was part of a wider, multi-stage procedure of lawmaking: nomothesia. This procedure had been created at the end of the fifth century BCE, after the restoration of democracy. It underpinned the newly instituted distinction between nomoi (laws) and psephismata (decrees), by providing a more complex route for enacting nomoi, different from the regular one for enacting psephismata. $^{20}$

The distinction was between nomoi as general permanent rules and psephismata-'situational' enactments, ad hoc decrees valid in a specific context, at a specific time, and for a limited time, or meant for one person only. ${ }^{21}$ All general permanent rules-nomoi-were conceptualized as higher-level rules and accordingly enacted through a different procedure (nomothesia). And all were binding on lower-level enactments (psephismata; see Andoc. 1.87; Dem. 23.218; 24.30; Hyp. Ath. 5.22). Thus, the sovereign power of the demos in the Assembly was limitedbound by a set of higher-order rules-and the demos could not freely enact anything it wished. The Athenians had in fact a public charge that could be brought against decrees-lower-level enactments—-that contradicted existing laws: graphe

\footnotetext{
${ }^{20}$ I have discussed the development of the distinction between nomoi and psephismata, and the origins of nomothesia, in Canevaro (2015), with full bibliographical information.

21 Hansen $(1978,1979)$.
} 
paranomon. The case would be heard by a lawcourt, and whoever brought the charge had to state in the graphe-the written indictment-what nomoi exactly the psephisma contradicted. Thus, any decree of the Council or of the Assembly was meant to be consistent with every single piece of existing and valid legislation (nomoi).

Nomoi were not enacted through simple Assembly procedure, ${ }^{22}$ but through a more complex procedure of nomothesia. I summarise here the procedure according to my own reconstruction, which I have argued at length elsewhere. ${ }^{23}$ In fourth-century Athens, to pass a law, the demos first acted in the form of the Council of Five Hundred, selected by lot. The Council set the agenda for the Assembly, and could be persuaded to put nomothesia in the agenda of the next Assembly. At that point, the Assembly (composed potentially of the whole demos, and very rarely of less than 6000 people) held a preliminary vote not on new law proposals, but on whether laws could be proposed at all. The institutional set-up was such that the first vote in the Assembly was not on a particular solution, but on whether the demos recognised that there was a problem that needed solving through legislation. If the vote was successful, then volunteers could propose new laws, which had to be widely publicised for a month. At the end of the month, the Assembly would set a date for the meeting of the nomothetai to enact new laws. There was however a concern for the coherence of the laws. Thus, before enacting new laws, the proposers had to repeal all existing contradictory laws, arguing that their new laws were more epitedeion ('appropriate', 'fit' to be laws of the city) than the ones they were repealing, and this occurred not in the Assembly, but in a lawcourt, against advocates of the contradictory laws elected by the Assembly at the end of the 'publicity' month. Once this was done, there would be the session of the nomothetai, and the nomothetai would finally approve the new law(s). But if it turned out that the proposer had not followed the correct procedure to the letter, had not properly publicised his proposal, or had failed to repeal a contradictory existing law, then anyone could bring a public charge against him (graphe nomon me epitedeion theinai), and he (and his bill) would be judged by another lawcourt, in a form of judicial review. Judicial review stages were not concerned exclusively with minute contradictions with existing statutes, but with the coherence of the nomoi under examination with the laws in their entirety, with their overall ethos. ${ }^{24}$

It is through such cases of judicial review that we learn the most about actual proposals for fiscal reform in the mid-fourth century BCE. This is the case with the law of Leptines: the speech Against Leptines was pronounced by Demosthenes as an accusation speech in a graphe nomon me epitedeion theinai. It was part of a procedure of nomothesia started by Apsephion, Phormion and Demosthenes with the aim of enacting a new law, to replace Leptines'. The law of Leptines had been stably enacted (more than one year earlier), had become fully one of the existing

\footnotetext{
22 About which see the synthesis in Hansen (1987), and now Canevaro (2018a) on the deliberative nature of Athenian political decision making.

23 Canevaro (2013a, b, 2016b). My reconstruction has been challenged by Hansen (2016a, b) (which defend Hansen's own old reconstruction), to which I respond comprehensively in Canevaro (2018b).

24 I make the case for judicial review in Canevaro (2018c).
} 
laws, and Leptines was no longer personally liable-his participation in the trial followed his election (with others) as syndikos of the existing law, while the accusers were attempting to repeal it because repealing contradictory laws was mandated by nomothesia before enacting a new one. ${ }^{25}$ The accusers state that, after repealing this law, they would submit their new law to the nomothetai for approval. Demosthenes argues that the law of Leptines is me epitedeios: it is a bad law (inferior to the one he proposes) because it is inconsistent with specific existing laws that Leptines did not repeal in advance, and with the ethos of the laws as a whole, and fully inadequate also in tackling the problems it aims to address - the shortage of available liturgists.

\section{The liturgical system}

Before discussing the law of Leptines, I provide some background on the Athenian liturgical system. Liturgies were a form of taxation: the wealthiest Athenians (and, in many cases, foreign residents) were obliged to finance and organise particular public services to the benefit of the community. ${ }^{26}$ Unlike normal taxation, however, the liturgical system was characterised by a certain level of voluntarism and by some discretion about the level of expenditure required, and many liturgies featured some form of competition, which incentivised higher expenditure to outdo other liturgists and obtain the demos' gratitude. ${ }^{27}$

Some evidence indicates that there was a minimum level of wealth under which liturgies could not be imposed on someone (cf. Dem. 20.19). If such a threshold existed, it would have formally identified a liturgical class. ${ }^{28}$ Most of the evidence however simply states that one's wealth was sufficient or insufficient, and little else. The rule is likely to have been that liturgies should be assigned to the wealthiest among those available who could afford them. ${ }^{29}$ One could avoid a liturgy through a procedure called antidosis: he could indicate someone else wealthier and available who had not been asked. The individual indicated had two options: undertaking the liturgy or agreeing to swap his estate with whomever had indicated him. ${ }^{30}$ The number of those who could be subjected to liturgies was therefore variable, but it gravitated around the figure of 1200 (out of a citizen population of around 30,000),

\footnotetext{
25 For the procedure followed in this speech, see Canevaro (2016a: 12-32, 71-76, b).

26 See the notes throughout this section for secondary literature on liturgies. For an up-to-date introductory discussion see Migeotte (2014: 524-529) (283-292 on liturgies outside Athens).

27 See Canevaro (2016a, b: 77-98). Christ (2006) highlights occasional attempts to shirk one's duties, but the system seems to have been by and large successful in making the wealthy perform their (expensive) duties. See Liddel (2007: 262-282).

${ }^{28}$ Harrison (1971a, b: 235). Ruschenbusch (1985) estimates the threshold at four talents and 1000 drachmas.

29 Rhodes (1982, 2006: 331). See also Gabrielsen (1994: 45-53), Christ (2006: 155) and Migeotte (2014: 524) notes that land registers must have helped to identify suitable estates.

30 Davies (1971: XXII), MacDowell (1978: 162-164), Ober (1989: 199), Gabrielsen (1987) and Christ (1990, 2006: 143-204). Another way to avoid a liturgy was the procedure of diadikasia.
} 
a figure later institutionalised in the trierarchic symmories. ${ }^{31}$ Davies argued that in the fourth century BCE those who owned a capital of less than three talents never undertook liturgies while those who owned more than four talents were bound to be selected. $^{32}$

The Athenians drew a distinction between ordinary and extra-ordinary liturgies. ${ }^{33}$ Ordinary liturgies were to do with public festivals, involving considerable expenditure and organisational responsibilities: ${ }^{34}$ the choregoi were in charge of funding and preparation of the choruses for the Athenian festivals (Great Dionysia, Lenaia, Thargelia, Panathenaia); gymnasiarchs of the races with torches (at the Hephaistia, Promethia, Panathenaia); hestiatores of the tribal banquets (at the Great Dionysia, Panathenaia, Thesmophoria). There were further liturgies for minor or foreign festivals, also compulsory for Athenian citizens. ${ }^{35}$ Extra-ordinary liturgies meant military ones: trierarchy (the funding and maintenance of a warship: a trireme), eisphora (actually a form of direct taxation for war costs, not precisely a liturgy) and proeisphora (the duty to advance the eisphora payment for an entire contributive group ${ }^{36}$ ). While eisphora was long an occasional contribution, trierarchy became soon an annual liturgy. Some liturgies were for metics only (foreign residents: e.g. skaphephoria-metics were meant to bring to the Panathenaia bowls full of offerings-or connected to particular cults reserved to them). ${ }^{37}$ Some were reserved for citizens, such as the trierarchy. ${ }^{38}$ But most ordinary liturgies were open to both categories. ${ }^{39}$ Davies calculated that there were at least 97 liturgies (excluding dubious cases) in a normal year, and 118 in Panathenaic years (one year in four had more liturgies on account of the festival of the Great Panathenaia). ${ }^{40}$

Choregies were the most important and most expensive of ordinary liturgies: Lys. 21.1 shows that they could cost up to half a talent-the speaker argues that he spent

\footnotetext{
31 See Rhodes (1982: 1-19), Gabrielsen (1994: 178-182), van Wees (2011: 111-112); contra Davies (1981: 26-27), Kron (2011: 129), who argue (implausibly) that they were 300.

32 Davies (1971: XXIV, 1981: 28-37). Cf. Rhodes (1982: 5), Gabrielsen (1994: 45-53, 176-82) and Migeotte (2014: 524).

33 See Migeotte (2014: 524). Ordinary liturgies were called enkyklioi, a term found also in two inscriptions (IG II $^{2} 1147$ and SEG 23.78), which probably derived from the circular choruses funded by many of these liturgies; see Wilson (2000: 332) n. 22.

34 See Lys. 21.1-5 for choregies between 300 and 3000 drachmas; IG $\mathrm{II}^{2} 417$ col. 11 . 5 for eutaxia between 50 and 100 drachmas; cf. Davies (1971: 21-22; 1981) and Pritchard (2015: 34). On organisational duties see e.g. Lys 19.58; cf. Hansen (1999: 110-112) and Wilson (2000: 50-108).

35 Davies (1971: XVII-XXXI, 1981), Wilson (2000: 11-108) and Makres (1994) provide comprehensive treatments of ordinary liturgies.. Cf. Migeotte (2014: 524-529).

36 See Wallace (1989) with further bibliography, and particularly de Ste. Croix (1953), Brun (1983), Hansen (1999: 110) and Christ (2006).

37 E.g. Whitehead (1977: 88-89).

38 E.g. Whitehead (1977: 81-103, n. 85); Gabrielsen (1994: 61). Contra Jordan (2001). Two possible exceptions: the Pamphilus of Dem. 21.163 and $I G$ II $^{2} 1612$ 11. 156-85, see MacDowell (1990: 382-383).

39 See Dem. 10.18 and Lys. 12.20; Whitehead (1977: 80-82), Hansen (1999: 110-111); cf. Wilson (2000: 28-31) about the Lenaia.

40 Davies (1967) and Pritchard (2015: 34-39, 44-49).
} 
14,900 drachmas (almost two and a half talents) over eight years in choregies. ${ }^{41}$ The most prestigious and expensive military liturgy was the trierarchy, which involved the upkeep of a trireme for one year. The trierarch was also meant to command the trireme, under the orders of the strategoi (generals), but had the option of appointing (and paying for) a commander to replace him. ${ }^{42}$ A trierarchy cost approximately one talent, a very substantial figure (Lys. 21.2, Lys, 32.24, Dem. 21.155), so expensive that the system was at one point reformed to allow for two individuals to share a trierarchy, ${ }^{43}$ and later further reformed to distribute the burden among symmoriai (contributive groups). ${ }^{44}$

Eisphora was a direct tax — not a liturgy proper, but a military tax that developed side by side with the liturgies and with the trierarchy and conditioned their organisation. It is often mentioned together with liturgies as evidence of the public spiritedness of a litigant (Isae. 7.39-40; Dem. 28.4; Lys. 20.23; 21.3; 19.43), because it was understood as a duty of the wealthier citizens and (for a specific portion of them) metics that brought with it honour and recognition. ${ }^{45}$ In its Classical version, it was originally a sporadic tax imposed on the wealthiest, but was transformed, from $347 / 6$ onwards, into an annual tax meant to collect an overall figure of ten talents, on top of which an extra-ordinary further eisphora could be added. ${ }^{46}$

The information on the earliest phase of eisphora (attested from 428 BCE in Thuc. 3.19.1, and possibly earlier in $I G \mathrm{I}^{3} 52$, 1l. b15-19) is patchy. Some argue that it was already calculated (as after 378/7 BCE) by applying a particular rate (decided each time by the Assembly) to the timema, the estimated capital of each of the wealthier citizens liable to it. Others believe that the calculation based on timema was introduced in 378/7, whereas earlier on all those liable paid the same amount (which varied depending on the total needed) ${ }^{47}$ It is also unclear how many Athenians were liable in this phase, with estimates between 6000 and $1000 .^{48}$ It is also possible that the number changed depending on need. ${ }^{49}$

\footnotetext{
${ }^{41}$ Wilson (2008: 111-114) estimates the cost of the Dionysia: ca. 415 BCE, liturgies contributed between 10 and fifteen talents to the Great Dionysia (cf. Pritchard 2015: 40-8). In the fourth century BCE, they contributed around seven talents and 2000 drachmas to the Great Panathenaia (Pritchard 2015: 28-40).

${ }^{42}$ For a comprehensive discussion of trierarchy, see Gabrielsen (1994) and Gabrielsen (2014) on the economics of Greek navies. See also Morrison et al. (2000: 107-126), Migeotte (2014: 527-529). For the prestige of trierarchy, see Liddel (2007: 270-274).

${ }^{43}$ Lys. 31.24-26; Dem. 21.154; cf. Gabrielsen (1994: 173-176).

${ }^{44}$ See Pritchard (2015: 99-113) on the cost of the fleet.

45 See Liddel (2007: 276). See in general de Ste. Croix (1953), Thomsen (1964), Brun (1983), Picard (2000: 152-156), Christ (2007), Flament (2007: 88-94, 191-192, 202-206, 222-223), Poddighe (2010) and Migeotte (2014: 518-524). It is found also in other cities, see Migeotte (2014: 278-283).

${ }^{46} I G \mathrm{II}^{2} 244$ 11. 12-13; 505 11. 14-17; Din. 1.69. Cf. Thomsen (1964: 238-242), Brun (1983: 54-55), Hansen (1999: 112), Christ (2006: 147).

${ }^{47}$ Cf. de Ste. Croix (1953: 34 n. 20), Thomsen (1964: 183), Davies (1971: 593; 1981: 146), Brun (1983: 9), Rhodes (1994: 193), Christ (2006: 148, 2007: 53-60) and Poddighe (2010).

${ }^{48}$ Ste. Croix (1953: 33): 6000 plus 1000 metics, Jones (1957: 29: 6000) and Davies (1981: 141: 10001200).

${ }^{49}$ Liddel (2007: 275).
} 
In 378/7 the system was thoroughly reformed, with the introduction of symmories: 100 contributive groups (Cleidemus $F G r H 323 \mathrm{~F} \mathrm{8}$ ), ${ }^{50}$ with around 15 wealthy contributors in each ${ }^{51}$ - the figure to be collected was divided among the groups, ${ }^{52}$ to which the rate established by the Assembly was applied, possibly with proportional taxation for each individual within them based on the declared timema. ${ }^{53}$ After 378/7 ca. eisphora was therefore collected from the wealthiest ca. 1500 citizens. The actual figure may in fact have been slightly higher, in the region of 2000. The eisphora was therefore paid by a larger group than the 'liturgical class' (around 1200 individuals), but nevertheless by the wealthiest Athenians. ${ }^{54}$ Historians have also calculated that it was collected at a rate normally higher than $0.25 \%$ of the total timemata (the assessed overall capital of all contributors). It is less clear how the individual timemata, which determined the figure to be paid, were assessed each time. Dem. 27.7 seems to suggest that the figure of each timema was negotiated, in a more or less formal agreement, between individual contributor and his symmory, with some room for flexibility. ${ }^{55}$

With the law of Periander of 358/7 BCE (Dem. 47.21), trierarchies were also organised in symmories: ${ }^{56} 20$ symmories of around 60 citizens each, for a total of 1200 contributors. ${ }^{57}$ This new trierarchical system institutionalised the number of liturgists. This reform is a reflexion of the difficulties in finding enough trierarchs encountered at the time of the Social War. These symmories were probably created ex novo, and were different from those of eisphora. The different number of symmories in the new system confirm this. ${ }^{58}$ Some scholars have argued, with various nuances, that the two systems were in fact identical, but that only the wealthiest 300 performed the trierarchy. ${ }^{59}$ Gabrielsen has however unequivocally demonstrated that at least 1200 individuals with fortunes over 3-4 talents, available to serve personally as trierarchs, were necessary for the trierarchical system to work at all. ${ }^{60}$ Rhodes also notes that passages such as Dem. 20.28, which state that not all that paid the eisphora were also liable to the trierarchy, ${ }^{61}$ are more easily understood if we envision two separate systems of symmories, with the members of the eisphora symmories being not 1200 , as in the trierarchy symmories, but more (possibly between

\footnotetext{
50 Philochorus FGrH 328 F 41; Hyp. frr. 102, 149, 152 Jensen.

51 For a detailed argument for these figures see Canevaro (2016a: 51 n. 211).

52 For opinions on the introduction of this system see Thomsen (1964), MacDowell (1986), Hansen (1999: 113), Rhodes (2006: 330) and Poddighe (2010).

53 The overall total of all the timemata for eisphora taxation in 379/8 was, according Plb. 2.62.7, 5750 talents; it was in 354/3, according to Dem. 14.19, 6000 talents. Poddighe (2010) argues instead that the timema system was effective from the beginning of eisphora. Cf. Migeotte (2014: 20-22). For accounts of the debates about whether progressivity applied within this system see Ste. Croix (1953: 35, 69-70), Thomsen (1964: 16-23), Brun (1983: 10-14), Christ (2007: 59) and Migeotte (2014: 521).

54 Rhodes (1982: 8).

55 Liddel (2007: 276). Cf. Poddighe (2010), Migeotte (2014: 519-522).

56 Dem. 47.21-22, 44; Dem. 14.16-17; Dem. 18.102-104; Dem. 21.154-155 with Gabrielsen (1994: 182-199).

57 Cf. Rhodes (1981: 680-681), MacDowell (1986) and Gabrielsen (1994: 182-193).

58 F.A. Wolf (1789: CI-CXVI), Boeckh (1886 I, pp. 609, 615, 618, 647), Thumser (1880: 63), Kahrstedt (1910: 224), de Ste Croix (1953: 45), Jones (1957: 28), Thomsen (1964: 88-89).

59 Ruschenbusch (1978, 1985), Mossé (1979: 31-42) and MacDowell (1986: 440).

60 Gabrielsen (1994: 45-53, 176-182).

61 See Canevaro 2016a, b: 238-239.
} 
1500 and 2000). ${ }^{62}$ The existence of two parallel systems both called symmories is not problematic. The recently published Grain Tax Law of Agyrrhius about the dodekate and the pentekoste taxes in Lemnos, Imbros and Skyros stipulates that 3000 medimnoi-worth portions of the tax should be collected by symmories of six individuals, responsible then to the city for handing over the grain (ll. 31-6). ${ }^{63}$ This provision shows that symmory (symmoria) was a generic term applied to all kinds of contributive groups, and not to a specific one. There is no need therefore to believe that every time the word appears it must refer to the same system of contributive groups (symmoriai). In fact, at Dem. 20.23 Demosthenes proposed to create a further system for the ordinary liturgies - these would be different symmories, differently organised (see Sect. 4).

Demosthenes proposed a further reform of the system in 354/3 BCE (Dem. 14): that the number of contributors should be expanded from 1200 to 2000, and that the rate of trierachic contributions should be proportional to the wealth of the individual contributors. His proposal was probably modelled around the symmories for eisphora, but it did not pass. ${ }^{64}$ More than a decade later, in $340 \mathrm{BCE}$, at the outset of the war with Philip II of Macedon, when Demosthenes was in a position of strength, he managed to have another reform approved, which transferred the burden of the trierarchies completely or for the most part on to a smaller group of the three hundred wealthiest citizens (Dem. 18.102-109; Aeschin. 3.222; Din. 1.42; Hyp. fr. 134 Jensen). ${ }^{65}$

Demosthenes' proposals are symptomatic of the crisis of the liturgical system, with the Athenians considering options for reform. War and economic crisis reduced the number of available liturgists with a capital of over 3-4 talents (by impoverishing many Athenians, also from the upper echelons of society), and must have reduced even further the number of those who undertook liturgies voluntarily. In that context, the system was often criticised, particularly for how burdensome ordinary liturgies were: some argued that military liturgies should have priority over festival ones, others that the entire system needed reforming. Demosthenes himself, at Dem. 20.26, argues that the aim of ordinary liturgies is to provide enjoyment for the audience, whereas the aim of military liturgies is the safety of the city; that the effects of ordinary liturgies are limited to fewer people who take part in the festivals, and to specific periods of time. ${ }^{66}$ Lycurgus (1.139-40) argues that the wealthy should not ask for the city's gratitude because of services such as choregies and horse breeding, which anyway provide them and their families (more than the city) with advantages and rewards (crowns). They should ask for gratitude for the trierarchies, for building the walls, for donations to support the war effort. Aristotle in the Politics (1309a 14-20) also argues that democracies would do better to spare the wealthy from the

\footnotetext{
62 Rhodes (1982: 5-11). Cf. Gabrielsen (1994: 182-193), pace Hansen (1999: 112-115).

63 See for this law Stroud (1998), and the different interpretations of some of its provisions in Harris (1999) and Faraguna (1999); Jakab (2007) (followed by Faraguna's critical response), Moreno (2003); Magnetto et al. (2010).

64 Cf. Rhodes (1981: 680; 2006: 332).

65 Completely: Jones (1957: 88); Davies (1971: XXIX); Ruschenbusch (1978: 283). For the most part: Gabrielsen (1994: 153-158); Hansen (1999: 172-173).

66 See Canevaro (2016a, b: 236).
} 
expensive yet useless choregies and lampadarchiai. Demetrius of Phaleron asserts that for many families the tripod of the winner in a choregic competition is nothing more than that last libation of their exhausted fortune, and a cenotaph of many a fallen family ( $F G r H 228 \mathrm{~F} 25) .{ }^{67}$

\section{What did the law of Leptines say, and why?}

We turn now to the law of Leptines. It was probably enacted in $356 / 5$, in the last months of the Social War. ${ }^{68}$ In those months, the Athenians, financially prostrated and on the way to defeat, enacted various measures to promote diplomatic relations and trade as sources of prosperity for the city, as part of medium- and long-term policies to restore the city's economic and diplomatic (rather than military) supremacy. At the same time, the Athenians were plagued by a lack of resources to run the statemachinery in the short term. We have several examples of attempts to replenish the state coffers and ensure the working of the institutions of the state (see Sect. 1). The law of Leptines has similar aims.

It is clear that the law stated that 'no one of the citizens, the isoteleis and the foreigners is exempt' and that 'in the future it is not permitted to grant an exemption'-Demosthenes' quotes verbatim this part of the law already at Dem. 20.2, and repeats it often throughout the speech. The problem is: what kinds of exemptions are we talking about? And exemptions from what exactly?

MacDowell identified five kinds of ateleia in Athens: ${ }^{69}$ 1) ateleia from liturgies, which could be given as a honorary grant, but also derive automatically from having performed a liturgy the year before, or a trierarchy in the two previous years (orphans and heiresses also had ateleia from liturgies) ${ }^{70}$; 2) ateleia from military service, due to appointment to certain offices (Dem. 21.15, 39.16, [Dem.] 59.27); 3) ateleia from the obligation of serving as public arbitrator in one's sixtieth year, if one was away or in office ([Arist.] Ath. Pol. 53.5); 4) property in the silver mines was ateles (exempt) when one's estate was assessed for antidosis (Dem. 42.18); 5) a

\footnotetext{
67 See Wilson (2000: 264-271).

68 See Canevaro (2016a, b: 8-11).

69 MacDowell (2004: 127-128). Cf. Henry (1983: 241-243) and Migeotte (2014: 458-467). On ateleia outside Athens see Knoepfler (2001: 55-60) (for central Greece), Rubinstein (2009), Migeotte (2014: 102-119).

70 See Dem. 20.8, [Arist.] Ath. Pol. 56.3 and Dem. 50.9 for the rule that those who performed a liturgy were exempt the next year. A similar rule gave a two years exemption those who performed a trierarchy (Isae. 7.38; cf. Lys. 19.29, 21.5, Isae. 5.41). See Davies (1981: 16-17), Rhodes (1982: 3), Christ (1990: 149 n. 9), Gabrielsen (1994: 85-87), Van Wees (2004: 308 n. 31). The exemption was from all liturgies, not just from the trierarchy, see Canevaro (2016a, b: 222-223). It is unclear when the two years interval was introduced. Pace Karvounis (1999), Dem. 20.8 does not contradict Isae. 7.38 (it refers to normal liturgies, not to trierarchies), and it stands to reason that the exemption after an ordinary liturgy should be shorter than that after the more expensive trierarchy. See Lys. 32.24 and Dem. 14.16 for orphans, heiresses and cleruchs.
} 
metic could have ateleia from the metic tax. ${ }^{71}$ In addition to these, we find (convincingly restored) in an inscription ( $I G \mathrm{II}^{3} 393$ 1. 5), at [Arist.] Ath. Pol. 42 and at Dem. 20.60 the expression ateleia hapanton or panton (exemption from everything), or the word ateleia unqualified. MacDowell and others have convincingly argued that such an exemption would cover all sorts of obligations, customs and duties, being therefore particularly valuable to traders who would be exempt from harbour taxes and other taxes on imports and exports. ${ }^{72}$

At Dem. 20.29-40 Demosthenes wants to give the impression that the law abolishes all kinds of ateleia, including on trade taxes and customs. His first example of deserving benefactor who would suffer on account of Leptines' law is Leucon of Bosporus, the sovereign of a kingdom particularly rich in grain, which provided Athens with a considerable proportion of its essential grain imports (ca. 400,000 medimnoi, according to Demosthenes) ${ }^{73}$ Leucon had been exempted, presumably, from everything - not just from liturgies (as a non-resident of Athens, that would have been meaningless), but also from commercial taxes. ${ }^{74}$ Demosthenes quotes at Dem. 20.29 the key phrase of Leptines' law ('no one of the citizens, the isoteleis and the foreigners is exempt') and complains that it does not specify from what precisely citizens, isoteleis and foreigners cannot be exempt. He thus implies that the law of Leptines will affect all kinds of exemptions. Later Demosthenes (20.31-32) summarizes the benefits that Leucon has bestowed upon Athens: not only is he the biggest source of grain for Athens, but he has given ateleia from export taxes (3.3\%) both in Bosporus and Theodosia to all traders, regardless of their origin, who buy grain and bring it to Athens. This ateleia is important because it encourages merchants to sell Bosporean grain to Athens (and sell it cheaper). He then argues that it is unthinkable that Leucon would suffer being deprived of his ateleia in Athens but still allow the Athenians to retain theirs in his kingdom. Demosthenes attempts to equate the exemptions Leucon has in Athens with those that the Athenians have in the kingdom of Bosporus, and implies that Leptines' law will cancel all of Leucon's exemptions, even those on harbour, import and export taxes. He relies here on the same economic logic espoused by Xenophon (see Sect. 1), confident that it will resonate with the judges. The need to increase trade to fix the economy must have been widely felt, and this topic must have been in those years central to endless speeches in the Assembly, quite like talk of growth never leaves us these days in Europe and the US. Demosthenes uses the widely-felt need to secure a large volume of trade (and a comfortable provision of grain) against the law of Leptines, implying

\footnotetext{
71 On metics and the metic tax, see Canevaro (2016a, b: 223-225) with previous scholarship. This exemption was normally called isoteleia, but some inscriptions show that it could also be called ateleia [cf. Henry (1983: 244-245)].

72 See Henry (1983: 241-243), Knöpfler (2001: 56 n. 179, 58 n. 193), MacDowell (2004: 127-128); contra Lambert (2006: 136 n. 99), but see Canevaro (2016a: 56 n. 235).

73 For a thorough discussion of Leucon and of Athenian grain imports, which summarises previous scholarship, see Canevaro (2016a, b: 240-261).

74 Such an exemption from import and export taxes matched what Leucon had granted the Athenians. Cf. Schol. Dem. 20.113 Dilts; Hagamajer Allen (2003: 236), MacDowell (2004: 128-129), Oliver (2007: 22-23, 30-37). Engen (2010: 284) believes (wrongly) that the exemption from commercial taxes would have been applied only if Leucon had sailed himself for Athens, but see Canevaro (2016a, b: 249-251), Bresson (2000: 148), Oliver (2007: 22-37).
} 
that the exemptions Leucon loses with Leptines' law are equivalent to those that the Athenians will lose as a result of it.

The argument is effective. But is it also truthful? Is it true that Leptines' law affected exemptions from everything, because it did not specify what kinds of exemptions it abolished ? $^{75}$ In fact, Demosthenes' himself is clear at Dem. 20.18-28 that Leptines' prime concern was to make sure that there would be enough people available to shoulder the ca. 100 liturgies to be performed every year. Essential public services and the orderly running of the Athenian state depended on this. Leptines was trying to solve this problem of shortage of liturgists by abolishing exemptions from liturgies. This has nothing to do with exemptions from harbour, imports and exports taxes. And, in fact, at Dem. 20.128 Demosthenes quotes verbatim another clause of Leptines' law (hopos an hoi plousiotatoi leitourgosi: 'so that the wealthiest shoulder the liturgies') which makes clear that the law applied only to exemptions from liturgies, not to all exemptions. ${ }^{76}$ This clause states explcitly that the purpose of the law was to make sure that the richest (among the 1,200 liable) would shoulder the liturgies, and therefore limits the scope of the prohibitions 'no one of the citizens, the isoteleis and the foreigners is exempt' and 'in the future it is not permitted to grant an exemption' only to the exemptions from liturgies, not to all exemptions. ${ }^{77}$ Demosthenes at Dem. 20.29-40 wants to give the impression that all of Leucon's exemptions were abolished, but this impression is deceptive, and Demosthenes himself implicitly admits this when he suggests at Dem. 20.40 that Leucon may now be asked to perform a liturgy, or challenged in an antidosis: an absurd suggestion given that Leucon was not resident in Athens. The issue here was exemptions from liturgies, and from liturgies alone.

The text of the law, reconstructed from various quotations scattered throughout the speech (Dem. 20.2, 29, 97, 127, 128, 170) referred only to liturgies:

Leptines proposed: so that the wealthiest shoulder the liturgies, no one of the citizens, the isoteleis and the foreigners is exempt except the descendants of Harmodius and Aristogeiton, and in the future it is not permitted to grant an exemption.

So Leptines was concerned specifically with liturgies, because, apparently, there was a shortage of available liturgists, and the wealthiest did not shoulder them as they should, so liturgies had become a burden for the poorer members of the liturgical class. What was Leptines' solution then?

While at Dem. 20.29-40 Demosthenes gives the impression that the law has wider application than it actually has (and applies also to commercial exemptions), at Dem. 20.18-28 he argues that it fails to solve even the problem for which it was

\footnotetext{
75 As hypothesised e.g. by MacDowell (2004: 128) and Kremmydas (2012: 53).

76 Final clauses with hopos an are often used in inscriptions to state the aim of the measure (e.g. $I G \mathrm{II}^{2}$ 42 11. 6-7 and 21-2; IG II $^{2} 43$ 11. 9-10; IG II $^{2} 141$ 11. 20-1).

77 It was not, therefore, a redistributive measure meant to unburden the poor [see Canevaro (2016a, b: 66-67)], pace Burke (2002), because the liturgical burden was shifted within the same top $4 \%$ of the citizens, and had nothing to do with the poor.
} 
conceived. In that case, he deceptively exaggerated the consequences of the law; in this case he deceptively underestimates them, using figures, quite like modern politicians, to blind the judges to the unwarranted assumptions of his analysis. He states that liturgies are performed part by citizens and part by metics. None of these are exempt anyway from the trierarchy and from the special war contributions (eisphora $).{ }^{78}$ He then argues that the law of Leptines would not add much to the number of available liturgists, because the richest are anyway exempted because of their trierarchies, while those who do not own enough (3-4 talents) are automatically exempted. Whether they have an honorary exemption or not, these categories are always exempted anyway. So, the law of Leptines will not add anyone from these two groups. How about the metics? Perhaps some. Demosthenes claims that there may be 16, 20 even perhaps 30 more potential liturgists (metics and a few citizens) that will lose their honorary exemption. Such a small number will not change much: the shortage will remain, and this small gain cannot compensate the reputational (and commercial) damage the law of Leptines will produce.

Demosthenes' argument is superficially convincing. ${ }^{79}$ But can we really believe that an experienced politician like Leptines would enact such an ineffective law? Leptines' purpose was explicitly to remedy the shortage of potential liturgists, and to move the burden from the poorest among the 1200 to the richest. If Demosthenes is right, his law would produce a meagre 30 more liturgists (we could even double this, to account for Demosthenes' interest in underestimating this number; but it would still make little difference: these would anyway be exempted every second year), but create no transfer of the burden to the richest among the 1200, who would still be exempted because of the trierarchies. There is however one assumption in Demosthenes' discussion that is not confirmed by any of the quotations and paraphrases of the law throughout the speech. It is a tacit assumption that never comes to the surface, but determines Demosthenes' entire argument. This assumption is that Leptines' law applied only to honorary exemptions.

The law states that 'no one of the citizens, the isoteleis and the foreigners is exempt, except for the descendants of Harmodius and Aristogeiton' and that 'in the future it is not permitted to grant an exemption'. It specifies that the purpose of the law is that in the future the richest may perform the liturgies. So it forbids further grants of ateleia, it abolishes all exemptions from liturgies, but does not state anywhere that only honorary exemptions are to be abolished. This is Demosthenes' own assumption. As the law is phrased, it would also affect the exemptions that resulted from having performed a liturgy the previous year, or a trierarchy in the two previous years (and possibly even during the same year). It would mean that, against Demosthenes' claims, the richest would not always be exempted from the liturgies because they are trierarchs. They would still be liable, whether they are performing

\footnotetext{
78 This statement is strictly speaking incorrect, because we have epigraphical evidence of a grant of ateleia from the eisphora. See $I G \mathrm{II}^{2} 141$ 11. 29-36, with Canevaro (2016a, b: 20) [pace Migeotte (2014: 146)].

79 And it has been found convincing by many scholars, e.g. Sandys (1890: XI-XVIII), Schaefer (18851887: I, pp. 353, 391), Momigliano (1975: 247-248), Sealey (1993: 126), Badian (2000: 27-28), Burke (2002: 177-179), Rhodes (2006: 332), Worthington (2013: 78-79).
} 
or have performed a trierarchy or not, as long as they are still demonstrably richer than someone else of the 1200 (otherwise antidosis was available). Likewise, a very rich man who was choregos the year before would not be exempted from service if he is still demonstrably richer than someone else. If this is correct, Leptines' law would have precisely the effects Leptines claimed it had, freeing many recent trierarchs (see below) and 100 recent liturgists every year for further liturgical service, securing a steady provision of liturgists, and making sure that the richest would always be liturgists first.

Demosthenes does not explicitly argue against this interpretation; he just suppresses it. But it surfaces in his account, as an echo of Leptines' own arguments: at Dem. 20.20 he argues that there are not even five metics with honorary exemptions. He states: 'If he comes up with five, I admit I am talking nonsense. Let us assume that I am, that more than that number of metics will perform liturgies if the law is enacted and that no citizen will be exempt for serving as trierarch' (trans. Harris, my italics). The per absurdum admission 'that no citizen will be exempt for serving as trierarch' seems to come straight out of Leptines' own arguments, and has nothing to do with the number of exempted metics (metics cannot even be trierarchs). Demosthenes hides it straightway with a reference to the dishonour of the city. He then carries on to argue that there can be 16, 20, 30 new potential liturgists at the most. But surely, if 'no citizen will be exempt for serving as trierarch' the number of additional potential trierarchs will not be 30 , it will be many more (see below).

This is also confirmed by what Demosthenes states at Dem. 20.26: he states that one of the arguments of the defence is that most of the wealthy get richer anapauomenous, to which Demosthenes retorts that the wealth they accumulate is useful for the whole city, because it allows them to undertake expensive liturgies such as the trierarchies. The participle anapauomenous refers to the exemptions, and the verb anapauo, in the middle, means 'to rest', 'to recover', and therefore can only refer to a temporary pause from the liturgical burden. It cannot refer to honorary exemptions, which are not temporary, but forever (they are not, that is, pauses). The fact that Demosthenes uses here anapauomenous while reporting Leptines' arguments is further evidence that the law of Leptines was meant to abolish all exemptions from liturgies, also the temporary exemptions (one or two years long) obtained after performing a liturgy. This would have had huge consequences for the workings of the liturgical system.

It appears then that all exemptions from liturgies, not only the honorary ones, were abolished by the law. Demosthenes tries to suppress this, in order to argue that the law is ineffective-it fails to do what it was designed for. He can then argue that the meagre benefits of the law are easily offset by the enormous reputational damage for the city, and by the medium- and long-term disadvantages it will bring in terms of trade. But even while arguing all this, he concedes that Leptines' argument is in fact that trierarchs will no longer be exempted from the liturgies. Later, when discussing individual meritorious benefactors, Demosthenes uses the opposite strategy, and suggests (without proving it) that the law of Leptines may have wider application, and affect also exemptions from harbour, imports and exports taxes, with terrible consequences for the grain trade (see above). 
Demosthenes wants to have it both ways, he lies and suppresses. His is an accusation speech, and his purpose is to have the law repealed. But the problems addressed by the law of Leptines were real. After the Social War, with an ongoing economic crisis and general impoverishment, it is likely that it may have become difficult for the relatively less wealthy among the richest 1200 Athenians to find enough money to perform every second year expensive liturgies. It is even likely that some of them may have dropped under the 3 talents limit, and even those that did not may have been closer to 3 than to 4 talents. If, as Demosthenes admits and Leptines must have stressed, the richest were often exempted because of the trierarchies, finding enough liturgists must have become problematic, and the burden of the liturgies must have been overwhelming for many who were previously quite comfortable with it.

So what was the size of the problem that Leptines attempted to solve with his law? Each year ca. 100 liturgists had to be found, out of a pool of the richest 4\% of the Athenian population-ca. 1200 citizens with a wealth of at least 3-4 talents (see Section 3). The task does not in itself seem daunting, yet we must keep in mind that not all these 1200 potential liturgists were really available. First, no one could perform more than one liturgy per year, so those that were trierarchs in a given year were automatically exempt from ordinary liturgies. Second, ca. 100 people were exempt because they had performed an ordinary liturgy the previous year. Third, those that had performed a trierarchy in the previous two years were also exempt. Moreover, no one could be asked to perform the same ordinary liturgy twice, some liturgies had a higher age threshold (i.e. liturgists had to be older to perform them, e.g. Aeschin. 1.11), ${ }^{80}$ fortunes of appropriate size that happened to be in the hands of heiresses or orphans were also exempt (Dem. 14.16), and some must have been exempt because of honorary exemptions.

How many people were exempt because of the trierarchy? Athens had in the $350 \mathrm{~s}$ in the region of 300 triremes, but no more than 250 were serviceable in a given year. ${ }^{81}$ Of course, in a calm year, much fewer ships would have been in commission-Gabrielsen estimates 60 , possibly as a minimum. ${ }^{82}$ Therefore, some trierarchs would not have actually sailed and would have been, as Gabrielsen describes them, 'nominal'. However, before the reform of Periander and the creation of the trierarchic symmories, all serviceable ships, whether 'active' during the year or not, were assigned to trierarchs, so between 200 trierarchs (a very conservative estimate) and 300 (accounting for ca. one-fifth of the trierarchies performed jointly)

\footnotetext{
80 Aeschin. 1.9-11 with Gabrielsen (1994: 85), Wilson (2000: 55-56).

$81 I G \mathrm{II}^{2}$ (1611) 1.9: 283 ships in 357/356; IG $\mathrm{II}^{2}$ (1613) 1. 302: 349 in 353/352; IG $\mathrm{II}^{2}$ (1627) 11. 266269, 275-278: 392 triremes +18 quadriremes $=410$ in 330/329; 360 triremes +50 quadriremes +2 quinqueremes $=412$ in 325/324. See Ashton (1979), Gabrielsen (2014: 39).

82 Gabrielsen (1994: 216); see also Davies (1981: 16); cf. Pritchard (2015: 109) for the 370s. It should be noted however that the events of the Against Leptines take place at the end of the Social War, after years of intense naval activity.
} 
were nominated each year. ${ }^{83}$ There is no evidence suggesting that only 'active' (as opposed to 'nominal') trierarchs were exempted for the following two years. In fact, if only ca. 60 'active' trierarchs served in a given year, and if only these received the exemption, it is hard to see how finding trierarchs for the fleet, out of a pool of 1200 men, may have ever been a problem, or a particular burden in the long run, to the extent that reform became necessary. As 'nominal' trierarchs were assigned ships and were responsible for their maintenance, whether they were commissioned or not, it is likely that they all received exemption. ${ }^{84}$ The law of Leptines was enacted shortly after Periander's reform, towards the end of a burdensome war, and it is likely that the trierarchic exemptions affecting the selection for liturgies had originated under, and were still conditioned by, the old system. ${ }^{85}$

In this scenario, every year at least 200-250 potential liturgists were exempt because they were trierarchs. Another 400-500 were exempt because they had been trierarchs in the two previous years, because trierarchies were followed by two years of exemption from all liturgies. These were generally the richest among the 1200. If we add all these categories of exemption up, it becomes clear why Leptines proposed his law: out of 1200 potential liturgists, over 800 or 900 could be exempted in any given year because of liturgical service they were performing or had performed in the past, or because they were orphans, or heiresses, or had been granted honorary exemptions. ${ }^{86}$

The scenario following the reform of Periander and the creation of 20 symmories of around 60 citizens each for a total of 1200 contributors-which must have affected Leptines' longer-term thinking-is more difficult to unpack. The naval records of the epimeletai ton neorion ('superintendents of the dockyards') show that ships, after the reform, were still assigned to individual trierarchs or (more rarely) to syntrierarchs. It is unclear whether the ships not in commission were still allocated to particular trierarchs or were simply left in the general care of a particular symmory. If they were still allocated to particular trierarchs (in addition to falling within the remit of a symmory), then the scenario would not be different from that described above, and all trierarchs ('nominal' and 'active') would be exempted. If, on the other hand, the ships not in commission were left in the generic care of the symmories, ${ }^{87}$ it is unclear who would receive the exemption: only the 'active' trierarchs or all the trierarchs/synteleis (contributors)? In the first case, we would be talking, on Gabrielsen assumption of sixty ships in commission, of ca. 80 per year (accounting for syntrierarchies), and it would be hard to see how this may have created difficulties with finding enough liturgists (or trierarchs, of whom there was also a shortage, as shown in Dem. 14.16-18). And, moreover, there is no evidence

\footnotetext{
83 Gabrielsen (1994: 177-178). See also Gabrielsen (1994: 81): 'It seems likely, therefore, that all vessels, whether in commission or at home at the beginning of the year, were allotted among the newly designated trierarchs'. On the difference between 'nominal' and 'active' trierarchs see Gabrielsen (1994: 77-78).

${ }^{84}$ Gabrielsen (1994: 87) seems agnostic about this, but at p. 178 he decisively states that all trierarchs ('nominal' and 'active') were exempted for the following two years.

85 This discussion complements Canevaro (2016a, b: 58-59) and makes the basis for the estimates I provide there explicit.

86 Gabrielsen (1994: 177-178) therefore posits an average four years cycle for liturgists and trierarchs and calculates the necessary pool from it.

87 This is the position of Gabrielsen (1994: 77-78).
} 
for a substantive distinction between the two categories, which would underpin the assumption that the exemption was reserved for the 'trierarchs' as opposed to the synteleis (members of the symmories contributing together). ${ }^{88}$

Gabrielsen is convinced that it is unthinkable that all the 1200 members of the symmories may have received a two-year exemption - this would have required 3600 potential members. ${ }^{89}$ Yet Dem. 14.16 makes clear that, at least in the period that we are discussing, it was in fact proving impossible to find each year 1200 members for the twenty symmories-Demosthenes states that there were each year around 800 people exempted (for various reasons, including being 'ineligible', adynatos). Thus, only ca. 400 at that point actually joined the symmories each year, and this is the reason for which Demosthenes, in the speech On the Symmories (14), proposes to extend the number of eligible candidates to 2000, so as to provide 1200 actual members of the symmories each year. Gabrielsen convincingly interprets the adynatoi mentioned at Dem. 14.16 as 'legally ineligible', because, for instance, they were performing other liturgies. By the same token, it is possible and likely (given the high number, 800) that the adynatoi included also those exempted because they had performed a liturgy in the previous year, or a trierarchy in the previous two. ${ }^{90}$ If the exemption protected people also from joining the symmories as contributors (synteleis), not just from being 'active' trierarchs, then it becomes easy to account for the difficulty in finding 1200 members of the symmories, and for the very high number of the exempted, 800. We have very limited evidence for how many synteleis took care of a commissioned ship, and the figure provided by Dem. 18.104sixteen-is probably an exaggeration. Hyp. fr. 134 states that before the further reform of 340 trierarchies were performed by groups of six or seven men (synteleis, rather than actual trierarchs), and Gabrielsen has shown that this figure is probably reliable (although there must have been ships with fewer synteleis). ${ }^{91}$ Using again Gabrielsen's estimate of 60 ships in commission in a given year, the actual synteleis involved in active trierarchies each year as members of the symmories would be ca. 360 (assuming six synteleis per ship), strikingly consistent with the figure of 400 actual members of the symmories provided by Dem. 14.16. If these men were then exempted for two years, this would more or less exhaust the pool of 1200 available liturgists, make unavailable for liturgical service all the richest in the city, and make it impossible for the city to find consistently enough people for the new trierarchical symmories, which theoretically required 1200 members (even accounting for a significant number of voluntary liturgists forsaking their exemptions).

These scenarios are all quite speculative, and the state of the evidence does not allow to formulate anything but very hypothetical estimates based on informed assumptions about the institutional set-up of the liturgical and trierarchical systems. But, in all these scenarios, it is clear that the pool of available liturgists was rather small, and it is easy to see how it may have been difficult to find every year ca. 100

\footnotetext{
88 See Gabrielsen (1994: 194 and n. 47); pace MacDowell (1986: 443).

89 Gabrielsen (1994: 85-87, 177), Van Wees (2004: 308-310). See also MacDowell (1986: 443) and Canevaro (2016a, b: 58), corrected here.

90 Gabrielsen (1994: 74; 188-189).

91 Gabrielsen (1994: 196).
} 
new liturgists. Perhaps, normally, volunteers would have made up for the shortage of suitable candidates (exemption did not prevent one from volunteering). However, after the Social War, with the economic crisis, it is likely that volunteers became uncommon, and that even among the 1200 a growing number of people could argue that they no longer possessed the required three talents, and therefore escape liturgical service.

Leptines, by making the (ex-)trierarchs available for the liturgies, offered an effective solution to this problem, which forced the very rich to shoulder comparatively more of the liturgical burden, giving the less rich among the 1200 some respite. In doing this, however, he also abolished honorary exemptions.

Demosthenes himself did not deny the problem; he just did not like the solution: at Dem. 20.23 he suggests that a better way to solve the problem of the shortage of liturgists may be to create also for the ordinary liturgies contributory groups (symmoriai) like those used for the trierarchies. Why does Demosthenes not like Leptines' solution? Because in order to solve short-term issues it may damage Athens' recovery in the medium and long term. Demosthenes, like Xenophon, is well aware that honours, whether they bring economic benefit or not, are an important instrument to foster trade, and that trade is ultimately the key resource an Athens without empire possesses to secure wealth and abundant revenues. Repealing honours already awarded would damage the international trust in Athens, its ability to make credible commitments, and hamper the implementation of measures to increase the volume of trade in the Piraeus, from which ultimately depended Athens' prosperity. ${ }^{92}$ Demosthenes' attack on the law was eventually successful, and Leptines' law was repealed. $^{93}$

\section{Conclusions}

Demosthenes' speech Against Leptines allows us to see these wider issues as they were debated in the 350s, and as the measures that would secure Athens' recovery were created and implemented. These debates can at first sight look messy, and the voices involved deceptive and self-interested. As these debates unfolded, however, within the institutions of the state-the Council, the Assembly, the nomothetai, the lawcourts - and the (economic and fiscal) issues of the day were analysed by them from a variety of perspectives, slowly, economic and fiscal policy was collectively formulated, designed, enacted and implemented. The complexity and sophistication of Athenian public finances and economic policy highlighted in recent scholarship emerged from expertise which formed, materialised, and was questioned, through heated and heavily participated public debate, within the institutions of the Athenian state.

\footnotetext{
${ }_{92}$ For a detailed analysis of this argument, see Canevaro (2016a, b: 77-98).

${ }^{93}$ See Canevaro (2016a, b: 98-100).
} 
Acknowledgements I would like to thank the Leverhulme Trust, which has funded the research for this article with a Philip Leverhulme Prize. I would also like to thank the anonymous referees for several useful suggestions.

Open Access This article is distributed under the terms of the Creative Commons Attribution 4.0 International License (http://creativecommons.org/licenses/by/4.0/), which permits unrestricted use, distribution, and reproduction in any medium, provided you give appropriate credit to the original author(s) and the source, provide a link to the Creative Commons license, and indicate if changes were made.

\section{References}

Aperghis, G. G. (1997). A reassessment of the Laurion mining lease records. BICS, 42, 1-20.

Ashton, N. G. (1979). How many Pentereis? GRBS, 20, 237-242.

Badian, E. (2000). The road to prominence. In I. Worthington (Ed.), Demosthenes. Statesman and orator (pp. 9-44). London: Routledge.

Bissa, E. M. A. (2009). Governmental intervention in foreign trade in archaic and classical Greece. Leiden: Brill.

Bloch, D. (2004). The date of Xenophon's Poroi. $C \& M$, 55, 5-16.

Boeckh, A. (1886). Die Staatshaushaltung der Athener. 3 volumi. Berlin: G. Reimer.

Bresson, A. (2000). La Cité marchande. Bordeaux: Ausonius.

Bresson, A. (2015). The making of the ancient Greek economy: Institutions, markets, and growth in the city-states. Princeton: Princeton University Press.

Brun, P. (1983). Eisphora-syntaxis-stratiotika. Paris: Les Belles Lettres.

Burke, E. M. (1992). The economy of Athens in the classical era: Some adjustments to the primitivist model. TAPhA, 122, 199-226.

Burke, E. M. (2002). The early political speeches of demosthenes: Elite bias in the response to economic crisis. ClAnt, 21, 165-193.

Canevaro, M. (2013a). The documents in the attic orators: Laws and decrees in the public speeches of the demosthenic corpus. Oxford: Oxford University Press.

Canevaro, M. (2013b). Nomothesia in classical Athens: What sources should we believe? CQ, 63, 1-22.

Canevaro, M. (2015). Making and changing laws in Ancient Athens. In E. M. Harris, \& M. Canevaro (Eds.), Oxford handbook of ancient Greek law. Oxford: Oxford University Press. http://www. oxfordhandbooks.com/view/10.1093/oxfordhb/9780199599257.001.0001/oxfordhb-9780199599 257-e-4.

Canevaro, M. (2016a). Demostene, Contro Leptine. Introduzione, traduzione e comment storico. Berlin: Walter de Gruyter.

Canevaro, M. (2016b). The procedure of demosthenes' against leptines: How to repeal (and replace) an existing law. JHS, 136, 39-58.

Canevaro, M. (2018a). Majority rule vs. consensus: The practice of democratic deliberation in the Greek poleis. In M. Canevaro, B. Gray, A. Erskine, \& J. Ober (Eds.), Ancient Greek history and the contemporary social sciences. Edinburgh: Edinburgh University Press.

Canevaro, M. (2018b). 'The authenticity of the document at Dem. 24.20-3, the procedures of nomothesia

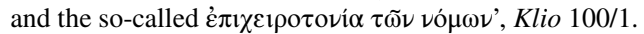

Canevaro, M. (2018c). Athenian constitutionalism: Nomothesia and judicial review. In U. YiftachFiranko \& G. Thür (Eds.), Symposion 2017. Vortrage zur griechischen und hellenistischen Rechtsgeschichte. Wien: Austrian Academy of Sciences.

Cawkwell, G. L. (1963). Eubulus. JHS, 83, 47-67.

Christ, M. R. (1990). Liturgy avoidance and Antidosis in classical Athens. TAPhA, 120, 147-169.

Christ, M. R. (2006). The bad citizen in classical Athens. Cambridge: Cambridge University Press.

Christ, M. R. (2007). The evolution of the Eisphora in classical Athens. CQ, 57, 53-69.

Cohen, E. E. (1973). Ancient Athenian maritime courts. Princeton: Princeton University Press.

Davies, J. K. (1967). Demosthenes on liturgies: A note. JHS, 87, 33-40.

Davies, J. K. (1971). Athenian propertied families. Oxford: Clarendon Press.

Davies, J. K. (1981). Wealth and the power of wealth in classical Athens. New York: Ayer Co Pub.

Davies, J. K. (2004). Athenian fiscal expertise and its influence. Mediterraneo Antico, 7, 491-512. 
de Ste. Croix, G. E. M. (1953). Demosthenes' TIMHMA and the Athenian Eisphora in the fourth century B.C. $C \& M, 14,30-70$.

Dillery, J. (1993). Xenophon's Poroi and Athenian Imperialism. Historia, 42(1), 1-11.

Engels, J. (1988). Anmerkungen zum 'Ökonomischen Denken' im 4. Jahrh. v. Chr. und zur wirtschaftlichen Entwicklung des Lykurgischen Athen. MBAH, 7, 90-132.

Engen, D. T. (2010). Honor and profit. Athenian trade policy and the economy and society of Greece, 415-307 B.C.E. Ann Arbor: University of Michigan Press.

Faraguna, M. (1992). Atene nell'età di Alessandro: Problemi politici, economici, finanziari. Roma: Accademia Nazionale dei Lincei.

Faraguna, M. (1999). Intorno alla nuova legge ateniese sulla tassazione del grano. Dike, 2, 63-97.

Flament, C. (2007). Une Economie Monetarisee: Athenes a L'epoque Classique 440-338: Contribution a L'etude Du Phenomene Monetaire En Grece Ancienne. Leuven: Peeters.

Gabrielsen, V. (1987). The Antidosis procedure in classical Athens. $C \& M, 38,7-38$.

Gabrielsen, V. (1994). Financing the Athenian fleet. Baltimore: Johns Hopkins University Press.

Gabrielsen, V. (2014). The Piraeus and the Athenian navy: Recent archaeological and historical advances. Proceedings of the Danish Institute at Athens, 7, 37-48.

Gauthier, P. (1976). Un commentaire historique des Poroi de Xénophon. Paris: Librairie Droz.

Gauthier, P. (1984). Le Programme de Xénophon dans les Poroi. RPh, 58, 181-199.

Giglioni, G. (1970). Xenophontis De Vectigalibus. Florence: La Nuova Italia.

Hagamajer Allen, K. (2003). Intercultural exchanges in fourth-century attic decrees. ClAnt, 22, 199-250.

Hansen, M. H. (1978). Nomos and psephisma in fourth-century Athens. GRBS, 19, 315-330.

Hansen, M. H. (1979). Did the Athenian ecclesia legislate after 403/2 BC? GRBS, 20, $27-53$.

Hansen, M. H. (1987). The Athenian assembly in the age of demosthenes. Oxford: Blackwell.

Hansen, M. H. (1999). The Athenian democracy in the age of Demosthenes. Structures, principles and ideology. London: University of Oklahoma Press.

Hansen, M. H. (2016a). The authenticity of the law about Nomothesia inserted in Demosthenes Against Timokrates 20-23. GRBS, 56, 438-474.

Hansen, M. H. (2016b). The authenticity of the law about Nomothesia inserted in Demosthenes Against Timokrates 33. GRBS, 56, 594-610.

Harris, E. M. (1996). Demosthenes and the theoric fund. In E. M. Harris \& R. W. Wallace (Eds.), Transitions to empire: Essays in Greco-Roman history, 360-146 B.C., in Honor of E. Badian (pp. 57-76). Norman: University of Oklahoma Press.

Harris, E. M. (1999). Notes on the new grain-tax law. ZPE, 126, 123-128.

Harris, E. M. (2015). The meaning of the legal term Symbolaion, the law about Dikai Emporikai and the role of the Paragraphe procedure. Dike, 18, 7-36.

Harris, E. M., Lewis, D., \& Woolmer, M. (Eds.). (2015). The ancient Greek economy: Markets, households and city-states. Cambridge: Cambridge University Press.

Harrison, A. R. W. (1971a). The law of Athens. Vol. 1: The family and property. Oxford: Clarendon Press. Harrison, A. R. W. (1971b). The law of Athens. Vol. 2: Procedure. Oxford: Clarendon Press.

Henry, A. S. (1983). Honours and privileges in Athenian decrees. Hildesheim: Georg Olms.

Hopper, R. J. (1953). The attic silver mines in the 4th century BC. ABSA, 48, 200-254.

Hopper, R. J. (1968). The Laureion mines. A reconsideration. ABSA, 63, 293-326.

Jakab, E. (2007). SEG XLVIII 96: Steuergesetz oder Frachtvertrag? In E. Cantarella (Ed.), Symposion 2005. Vortrage zur griechischen und hellenistischen Rechtsgeschichte (pp. 105-121). Wien: Austrian Academy of Sciences.

Jones, A. H. M. (1957). Athenian democracy. Oxford: Blackwell.

Jordan, B. (2001). Metic trierach. AHB, 15, 131-134.

Kahrstedt, U. (1910). Forschungen zur Geschichte des ausgehenden fünften und des vierten Jahrhunderts. Berlin: Weidmann.

Kallet-Marx, L. (1994). Money talks: Rhetor, demos and the resources of the Athenian empire. In R. Osborne \& S. Hornblower (Eds.), Ritual, finance, politics (pp. 227-251). Oxford: Clarendon Press.

Karvounis, C. (1999). Die Dauer der gesetzlichen Befreiung von der Trierarchie. C\&M, 50, 61-66.

Knöpfler, D. (2001). Décrets érétriens de proxénie et de citoyenneté. Lausanne: Payot.

Kremmydas, C. (2012). Commentary on Demosthenes' Against Leptines. Oxford: Oxford University Press.

Kron, G. (2011). The distribution of wealth at Athens in comparative perspective. ZPE, 179, 129-138.

Lambert, S. D. (2006). Athenian state laws and decrees 352/1-322/1: III Decrees honouring foreigners A. citizenship, proxeny and euergesy. ZPE,158, 115-158. 
Lambert, S. D. (2011). Some political shifts in Lykourgan Athens. In V. Azoulay \& P. Ismard (Eds.), Clisthène et Lycurgue d'Athènes: Autour du politique dans la cité classique (pp. 175-190). Paris: Publications de la Sorbonne.

Lambert, S. D. (2012). Inscribed Athenian laws and decrees 352/1-322/1 BC. Leiden: Brill.

Lewis, J. D. (2010). Xenophon's Poroi and the foundations of political economy. Polis, 26(2), 370-388.

Liddel, P. (2007). Civic obligation and individual liberty in ancient Athens. Oxford: Oxford University Press.

Liddel, P. (2016). The honorific decrees of fourth-century Athens: Trends, perceptions, controversies. In C. Tisch (Ed.), Athenische Demokratie im 4. Jh.-zwischen Modernisierung und Tradition (pp. 311-333). Stuttgart: Steiner.

Lowry, T. (1987). The archaeology of economic ideas. Durham: Duke University Press.

MacDowell, D. M. (1978). The law in classical Athens. London: Thames and Hudson.

MacDowell, D. M. (1986). The law of Periandros about symmories. CQ, 36, 438-449.

MacDowell, D. M. (1990). Demosthenes. Against Meidias 21. Oxford: Clarendon Press.

MacDowell, D. M. (2004). Epikerdes of Kyrene and the Athenian privilege of Ateleia. ZPE, 150, 127-133.

MacDowell, D. M. (2006). Mining cases in Athenian law. In H. -A. Rupprecht (Ed.), Symposion 2003. Vortrage zur griechischen und hellenistischen Rechtsgeschichte (pp. 121-131). Wien: Austrian Academy of Sciences.

MacDowell, D. M. (2009). Demosthenes the orator. Oxford: Oxford University Press.

Magnetto, A., Erdas, D., \& Carusi, C. (Ed.) (2010). Nuove ricerche sulla legge granaria ateniese del 374/3 a.C. Pisa: Edizioni ETS.

Makres, A. (1994). The institution of Choregia in classical Athens. Dissertation, University of Oxford, Oxford.

Migeotte, L. (2014). Les Finances des cités grecques. Paris: Les Belles Lettres.

Mitchell, L. G. (1997). Greeks bearing gifts: The public use of private relationships 435-323 BC. Cambridge: Cambridge University Press.

Momigliano, A. (1975). Contributi alla caratteristica di Demostene. In A. Momigliano (Ed.), Quinto contributo alla storia degli studi classici e del mondo antico (pp. 235-264). Roma: Edizioni di Storia e Letteratura.

Moreno, A. (2003). Athenian bread-baskets: The grain-tax law of 374/3 B.C. Re-interpreted. ZPE, 145, 97-106.

Moreno, A. (2007). Feeding the democracy. The Athenian grain supply in the fifth and fourth centuries $B C$. Oxford: Oxford University Press.

Morrison, J. S., Coates, T. F., \& Rankov, N. B. (Eds.). (2000). The Athenian trireme. The history and reconstruction of an ancient warship (2nd ed.). Cambridge: Cambridge University Press.

Mossé, C. (1979). Les symmories athéniennes. In H. van Effenterre (Ed.), Points de vue sur la fiscalité antique. Paris: Centre Gustave Glotz.

Ober, J. (1989). Mass and elite in democratic Athens. Retoric, ideology and the power of the people. Princeton: Princeton University Press.

Ober, J. (2008). Democracy and knowledge: Innovation and learning in classical Athens. Princeton: Princeton University Press.

Ober, J. (2013). Democracy's wisdom: An aristotelian middle way for collective judgment. American Political Science Review, 107(1), 104-122.

Ober, J. (2015a). Classical Athens. In A. Monson \& W. Scheidel (Eds.), Fiscal regimes and the political economy of premodern states (pp. 492-522). Cambridge: Cambridge University Press.

Ober, J. (2015b). The rise and fall of classical Greece. Princeton: Princeton University Press.

Oliver, G. J. (2007). War, food and politics in early Hellenistic Athens. Oxford: Oxford University Press.

Oliver, G. J. (2011). Before "Lykourgan Athens": The origins of change. In V. Azoulay \& P. Ismard (Eds.), Clisthène et Lycurgue d'Athènes: Autour du politique dans la cité classique (pp. 119-132). Paris: Publications de la Sorbonne.

Picard, O. (2000). Guerre et économie de la Grèce classique (490 av. J.-C.-322 av. J.-C.). Paris: Armand Colin.

Poddighe, E. (2010). Riflessioni sul fondamento etico-legale e sul carattere finanziario dell'eisphora ateniese tra V e IV sec. a.C. In M. R. Cataudella, A. Greco, \& G. Mariotta (Eds.), Strumenti e tecniche della riscossione dei tributi nel mondo antico (pp. 97-118). Padova: Sargon.

Pritchard, D. M. (2015). Public spending and democracy in classical Athens. Austin, TX: University of Texas Press. 
Rhodes, P. J. (1981). A commentary on the Aristotelian Athenaion Politeia. Oxford: Oxford University Press.

Rhodes, P. J. (1982). Problems in Athenian Eisphora and Liturgies. AJAH, 7, 1-19.

Rhodes, P. J. (1994). Thucydides history III, edited with translation and commentary. Warminster: Aris and Phillips.

Rhodes, P. J. (2006). A history of the classical Greek world. 478-323 B.C. Oxford: Oxford University Press.

Rhodes, P. J. (2010). A history of the classical Greek world. 478-323 B.C (2nd ed.). Oxford: Oxford University Press.

Rhodes, P. J., \& Osborne, R. G. (2003). Greek historical inscriptions. Oxford: Oxford University Press.

Roselli, D. K. (2009). Theorika in fifth-century Athens. GRBS, 49, 5-30.

Rubinstein, L. (2009). Ateleia grants and their enforcement in the classical and early hellenistic periods. In L. G. Mitchell \& L. Rubinstein (Eds.), Greek history and epigraphy. Essays in honour of P. J. Rhodes (pp. 115-143). Swansea: The Classical Press of Wales.

Ruschenbusch, E. (1978). Die athenischen Symmorien des 4. Jh. v. Chr. ZPE, 31, 275-284.

Ruschenbusch, E. (1985). Ein Beitrag zur Leiturgie und zur Eisphora. ZPE, 59, 237-240.

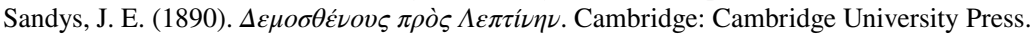

Schaefer, A. (1885-1887). Demosthenes und seine Zeit. 3 vols. Leipzig: Teubner.

Sealey, R. (1993). Demosthenes and his time. Oxford: Oxford University Press.

Shipton, K. (2000). Leasing and lending: The cash economy in 4th century BC Athens. London: University of London.

Stroud, R. S. (1998). The Athenian grain-tax law of 374/3 BC. Princeton: Princeton University Press.

Thomsen, R. (1964). Eisphora: A study of direct taxation in ancient Athens. Copenhagen: Gyldendal.

Thumser, V. (1880). De civium Atheniensium muneribus eorumque immunitate. Wien: Sumptibus et typis C. Gerold filii.

Van Liefferinge, K. (2018). Technology and Society in Classical Athens: A study of the social context of mining and metallurgy at Laurion. In M. Canevaro, A. Erskine, B. Gray, \& J. Ober (Eds.), Ancient Greek history and the contemporary social sciences. Edinburgh: Edinburgh University Press.

van Wees, H. (2004). Greek warfare: Myths and realities. London: Bristol Classical Press.

van Wees, H. (2011). Demetrius and Draco: Athens' property classes and population in and before 317 BC. JHS, 131, 95-114.

van Wees, H. (2013). Ships and silver, taxes and tribute. A fiscal history of archaic Athens. London: I. B. Tauris.

Vélissaropoulos, J. (1980). Les nauclères grecs: Recherches sur les institutions maritimes en Grèce et dans l'Orient hellenisé. Geneva and Paris: Librairie Droz.

Wallace, R. W. (1989). The Athenian Proeispherontes. Hesperia, 58, 473-490.

Whitehead, D. (1977). The ideology of the Athenian metic. Cambridge: Cambridge University Press.

Wilson, P. (2000). The Athenian institution of the Khoregia: The chorus, the city and the stage. Cambridge: Cambridge University Press.

Wilson, P. (2008). Costing the dionysia. In M. Revermann \& P. Wilson (Eds.), Performance, iconography, reception (pp. 88-127). Oxford: Oxford University Press.

Wolf, F. A. (1789). Demosthenis Oratio adversus Leptinem cum scholiis veteribus et commentario perpetuo. Halle: e libraria Hemmerdeana.

Worthington, I. (2013). Demosthenes of Athens and the fall of classical Greece. Oxford: Oxford University Press. 